\title{
Decision Support System with Fuzzy Tahani Method for Selection of Travel Destinations in Garut
}

\author{
Muhammad Ali Ramdhani ${ }^{1}$, Diena Rauda Ramdania ${ }^{2}$, Khaerul Manaf ${ }^{3}$, Aldi Surya \\ Pratama $^{4}$ \\ \{m_ali_ramdhani@uinsgd.ac.id ${ }^{1}$,diena.rauda@uinsgd.ac.id² \\ Department of Informatics Engineering, UIN Sunan Gunung Djati Bandung ${ }^{1-4}$
}

\begin{abstract}
Indonesia has high tourism potential. This needs to be supported by providing complete information to prospective tourists. One of the provinces with the most tourists is West Java. Unfortunately, there are still many natural potentials and districts in West Java that have not been widely known, one of which is Garut City. This paper will explain the implementation of Fuzzy Tahani into the information system that provides recommendations on tourism places in the City of Garut. Based on the results of testing, this information system can provide recommendations with several criteria, namely price, number of visitors, facilities available at tourist attractions, and distance from tourist sites. The Black box testing results showed that the system was able to pass the test stage and provide satisfactory results. This signifies the information system that provides recommendations for tourism places with Fuzzy Tahani running well.
\end{abstract}

Keywords: Decision support system, Fuzzy Tahani, Garut, Tourism.

\section{Introduction}

Based on data compiled by the Central Statistics Agency, as many as 15.81 million foreign tourists entered Indonesia in 2018[1][2]. This number rose from the previous year by $11.63 \%$ [3]. West Java is one of the favorite destinations for both local and foreign tourists [4]. Unfortunately, tourists visit more famous places, such as Lembang[5]. Though the tourism potential in the West Java region is very much and has not been explored, one of them is Garut.

Garut Regency is one of the tourist destinations in West Java Province which has a lot of interesting and interesting tourist destinations. From the side of the Garut Regency area in the mountainous region, the beautiful nature and natural atmosphere of the countryside are still thick. The tourism potential in Garut Regency can be classified into two parts, namely natural tourism such as hot springs, waterfalls, situ, beaches, craters, animal parks, and cultural tourism such as traditional villages, museums, pilgrimage. Until 2018, the Garut Regency Culture and Tourism Office noted that there were at least 31 attractions in Garut.

Ignorance of tourists about the potential of Garut invites the local government to take the tourism sector more seriously[6]. Seeing this development, we need a means of information that can make it easier for tourists to find out complete tourist attractions. One of them can be a tourist recommendation system.

In this paper, we will discuss the making and implementation of a system of tourism recommendations in the city of Garut. This system will implement the Fuzzy Tahani algorithm. This algorithm has been widely used and gives good results in giving recommendations. Like 
the recommendations of new students[7], determining the best graduates [8], choosing cars[9], prospective employees[10], scholarship candidates[11], travelling[12], etc.

\section{Fuzzy Tahani Method}

Fuzzy logic was first discovered by Professor Lotfi A. Zadeh, from the University of California, in June 1965. Fuzzy logic is a generalization of classical logic that only has two membership values, namely 0 and 1 . In fuzzy logic, the truth value of a statement ranges from completely true, until completely wrong. With fuzzy set theory, an object can be a member of many sets with different membership degrees in each set. This concept is different from the classic set (crisp). The classic set theory depends on the logic of two values to determine whether an object is a member of a set or not[8].

Fuzzy sets have 2 attributes, namely: Linguistics and numerical. Linguistics, namely naming a group that represents a certain condition or condition by using natural language, such as Young, Old, Middle-aged. Numerical means a value (number) that shows the size of a variable such as $40,25,50[8][12]$.

Several things need to be important in understanding fuzzy systems, namely variables, sets, speech universe, and domains. Fuzzy variables are variables that will be discussed in a fuzzy system. Example: age, temperature, demand. A fuzzy set is a group that represents a certain condition or condition in a fuzzy variable. Universe discussion is the whole value that is allowed to operate in a fuzzy variable. The talk universe is a set of real numbers which always rises (increases) monotone from left to right. The universal value of the conversation can be either positive or negative numbers. Fuzzy set domains are all values allowed in the universe of conversation and may be operated in a fuzzy set. As the universe of conversation, domains are sets of real numbers which always rise (increase) monotone from left to right. Domain values can be either positive or negative numbers.

Membership function (membership function) is a curve that shows the mapping of input data points into the value of membership (often also called the degree of membership) which has an interval between 0 to 1 [13]. Membership function (membership function) is a curve that shows the mapping of input data points into the value of membership (often also called the degree of membership) which has an interval between 0 to 1 [13]. One way that can be used to get membership value is through a function approach. Several functions can be used:

1. Linear representation, namely mapping the input to the degree of membership described as a straight line. In this representation, the curve can move up or down,

2. Triangle curve ia a combination of two lines (linear),

3. Triangle curve. Basically like a triangular shape, it's just that some points have a membership value of 1 , and

4. Representation of Curve-S. The S-curve is almost the same as the linear curve but the uncertain value is ascending or descending but is flexible. The area located in the middle of a variable represented in the form of a triangle, on the right and left side will rise and fall.

Fuzzy tahani is one branch of fuzzy logic, which is one fuzzy method that uses a standard database. Tahani describes a fuzzy query processing method, based on language manipulation known as SQL (Structured Query Language) so that the fuzzy tahani model is very suitable to be used in the process of finding the right and accurate data [14]. 


\section{Research Methods}

\section{a. Primary Data}

Primary data is data that is directly obtained from the agency. Obtained from the results of interviews and observations carried out by researchers to the Department of Tourism and Culture of Garut Regency and at the UPTD (Regional Technical Implementation Unit) related tourism objects. The data obtained by researchers are tourist facilities data, entrance ticket prices, and location distance data.

\section{b. Secondary Data}

Secondary data is data obtained by researchers by gathering theories and data materials that have a relationship with the problems being studied. Including visitor data on tourism objects in the last three years obtained from the Office of Tourism and Culture of Garutl Regency. Where later it can help researchers in completing this Final Project report. The data used is the average visitor for the last 3 years that has been processed from the initial data in the form of raw data for visitor reports every month from 2014 to 2016.

The results and discussion are part where the results of the research and discussion contain. The findings obtained from the results of the study must be written and illustrated with adequate data so that they can answer the hypothesis of the research in question. The processes in the Fuzzy Tahani development method are explained as follows.

\subsection{Fuzzy Variables}

Fuzzy variables for the Tourism menu include:

a. Amenities

b. Price Range

c. The number of visitors

d. Distance Location

\subsection{Membership Functions}

\section{a. Ticket Prices Tourism Object}

Price criteria, namely the price range of entry tickets for tourism objects that have been set in the tourist area of Garut and Kab. Garut. The tourism price criteria are divided into 3 fuzzy sets, namely cheap, medium, and expensive. Cheap and expensive sets use the approach to the membership function in the form of a shoulder, while the set is using a triangle-shaped approach. b. Tourism Facilities Many.

The criteria for tourist facilities are divided into 3 fuzzy sets, which are Little, Enough, and

c. Number of Tourist Visitors

The criteria for the number of tourist visitors in the tourist attraction are divided into 3 fuzzy sets, namely Lonely, Ordinary, and Crowded. The Lonely and Crowded Association uses a membership function approach in the form of a shoulder, while the Crowded set uses a triangle-shaped approach.

\section{d. Distance of Tourism Location}

Distance criteria are divided into three fuzzy sets, which are Near, Medium, and Far. The Near and Far set uses a membership function approach in the form of a shoulder, while the set is using a triangular approach. 


\subsection{Fuzzification stage}

Fuzzification is changing express values to fuzzy values. The data used in processing fuzzification is the initial data of tourism.

\section{Analysis and Design}

\subsection{Modeling System Requirements}

To make a system needs analysis is needed first so that the system that will be made does not deviate from the core system, namely the system used for recommendations on tourist attractions that are following what is desired. The system in modeling this need consists of functional requirements and a proposed system that will be built on the recommendations of tourist attractions. Following are the functional requirements of the system in Table 1.

Table 1. Functional Needs

\begin{tabular}{ll}
\hline No & Description \\
\hline 1 & The system can provide price categories with cheap, medium and expensive types. \\
2 & The system can provide facility categories with a few, enough, and many choices. \\
3 & The system can provide offline categories with lonely, ordinary, and crowded choices. \\
4 & The system can provide distance, near, medium and far choices. \\
5 & Tourists can see a list of attractions. \\
6 & Tourists can see a list of attractions recommended by the system. \\
7 & Tourists can choose and see detailed information about tourism objects. \\
8 & The system can exclude the Fuzzy Tahini algorithm. \\
9 & The system provides detailed tourist information. \\
\hline
\end{tabular}

In addition to the functional requirements, the next is the proposal system. As explained above, the proposed system for solving existing problems is to make an application for tourism recommendations in Garut Regency. The goal is to promote tourist attractions in Garut regency to help prospective domestic and foreign tourists in determining the tourist attractions they will visit in Garut Regency based on ticket prices, facilities, distance, number of visitors.

\subsection{Determination of Tourism Criteria Values}

The following is a simulation and stages to give an idea of how the fuzzy algorithm works in the application:

1. Determining tourism criteria Criteria - tourism criteria (variables) used as a basis for determining tourist recommendations using fuzzy tahani algorithm is the price of ordinary tickets (cheap, medium, expensive) distance (close, medium, far) the number of tourists (quiet, medium, crowded) and facilities (few, medium, many).

2. Describing membership functions or curves that show values between 0 and 1 , by way of performing membership functions. There are several combinations, combinations of triangular and trapezoidal membership functions, or linear membership functions. 


\subsection{Use Case Diagram}

The use case section, the diagram explains what can be done by the system to be built and who will interact with the system. Use case diagram becomes user activity. The use case diagram on the system to be built can be seen in Fig. 1 .

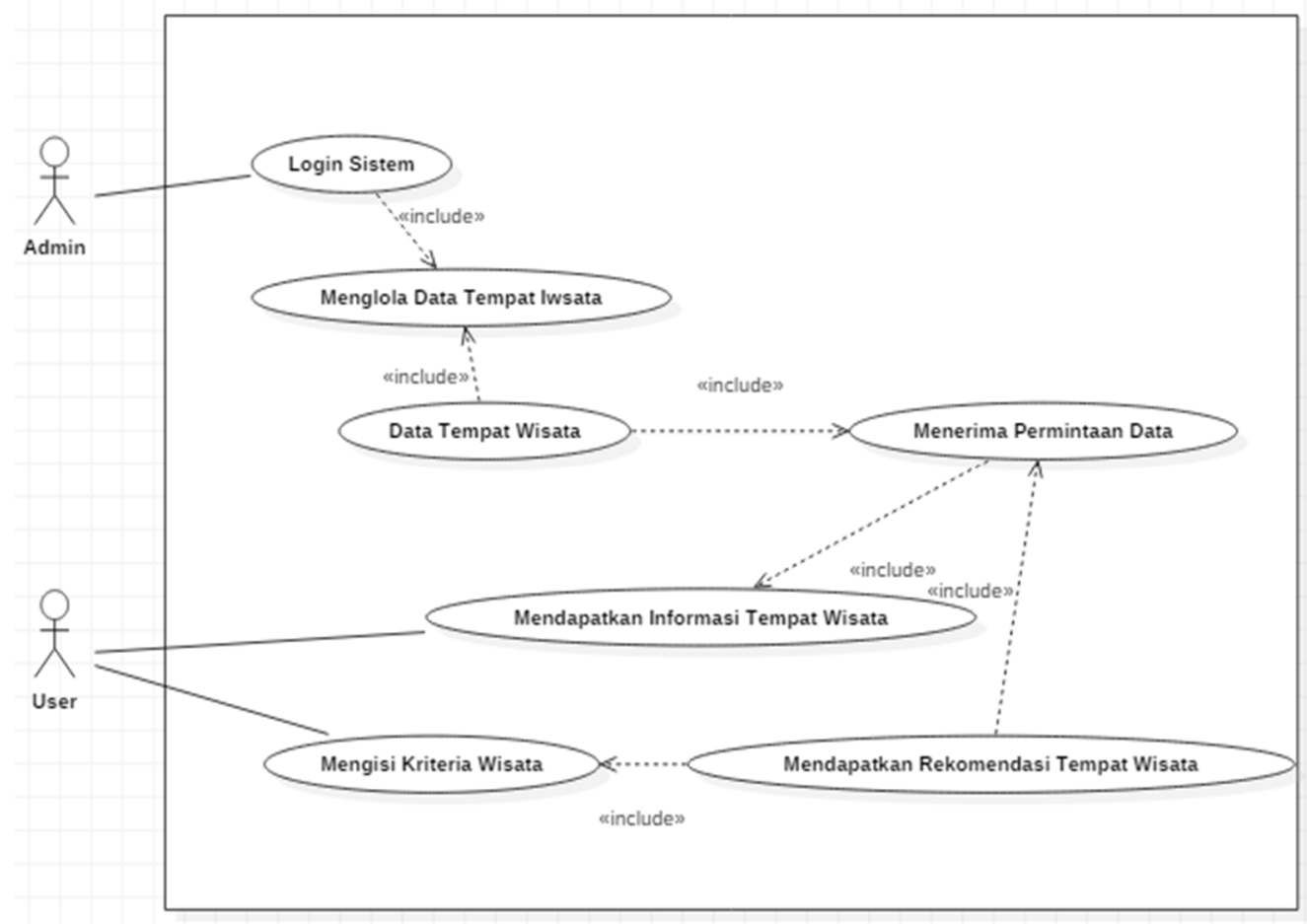

Fig.1. Use Case Diagram

\section{Result and Discussion}

The intended tourist needs are divided into several criteria such as the number of visitors who come, facilities owned, the distance that must be taken to reach the tourist attraction, the type of tourism you want to visit, to the costs that must be paid for tickets to enter a tourist attraction. The various attributes are summarized into several criteria as in Table 2.

Table 2. Fuzzy Criteria

\begin{tabular}{lllll}
\hline No & Ticket Price & Visitor & Facility & Distance \\
\hline 1 & Expensive & Crowded & Many & Far Away \\
2 & Moderate & Medium & Moderate & Medium \\
3 & Cheap & Empty & Slighty & Close \\
\hline
\end{tabular}


Because the Tourism Type variable is non-fuzzy, it is only used to classify the output of recommendations from tourism objects that have gone through a fuzzification process. The Fuzzy Tahani method is used to process the initial data, namely tourism criteria data to obtain a prediction of travel search decisions that are appropriate for the user. After all, stages are carried out with the fuzzy tahani method, later it will be known which types of tourism are more suitable for tourists to visit according to the criteria inputted by tourists.

\section{a. Ticket Prices}

This stage will process information from the entrance ticket price column for designated tourism objects in the tourist area of Garut and Kab. Garut. The tourism price criteria are divided into 3 fuzzy sets, namely cheap, medium, and expensive.

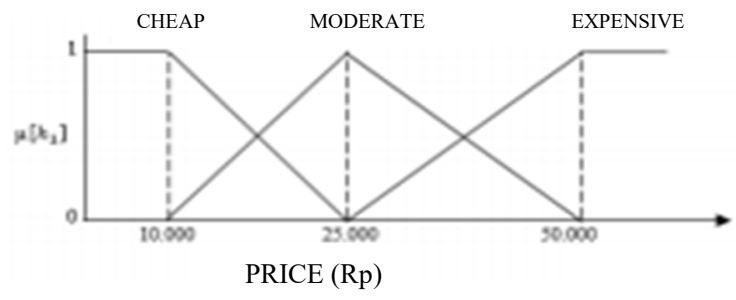

Fig.2. Graph of Price Membership Functions

After knowing the results of membership functions that have different values, namely Cheap, Medium and Expensive, the results obtained in the following table are tourism data based on price and the degree of membership in each set.

b. Tourism Facilities

The criteria for tourist facilities are divided into 3 fuzzy sets, which are Little, Enough, and Many.

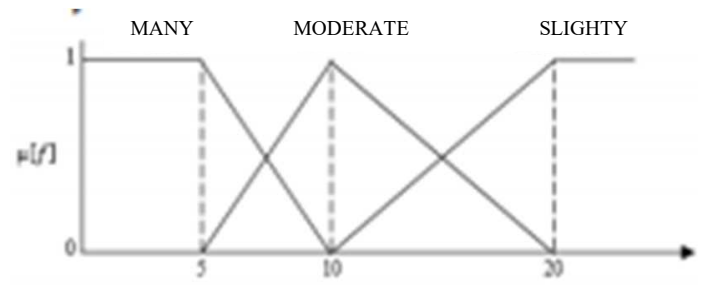

Fig.3. Graph of Facility Membership Functions

After knowing the results of membership functions that have different values, namely Little, Enough and Many, the results obtained in the following table are tourism data based on the number of facilities and the degree of membership in each set.

\section{c. Number of Tourist Visitors}

The criteria for the number of tourist visitors in the tourist attraction are divided into 3 fuzzy sets, namely Lonely, Ordinary, and Crowded. The Lonely and Crowded Association uses a membership function approach in the form of a shoulder, while the Crowded set uses a triangleshaped approach. 


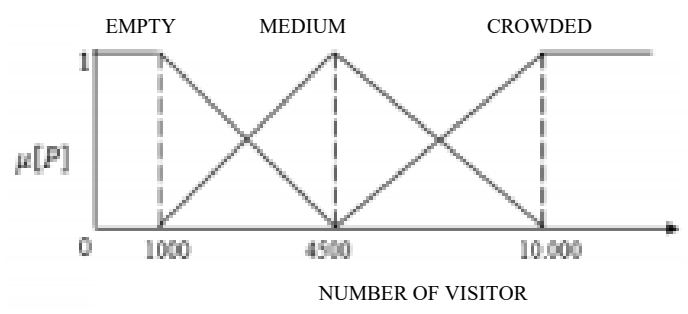

Fig.4. Graph of Function of Number of Visitors

After knowing the results of membership functions that have different values, namely Lonely, Crowded, and Ordinary results obtained in the following table, namely tourism data based on the number of visitors and the degree of membership in each set.

d. Distance Tourism Location

Distance criteria are divided into three fuzzy sets, which are Near, Medium, and Far. The Near and Far Association uses a membership function approach in the form of a shoulder, while the set is using a triangular approach.

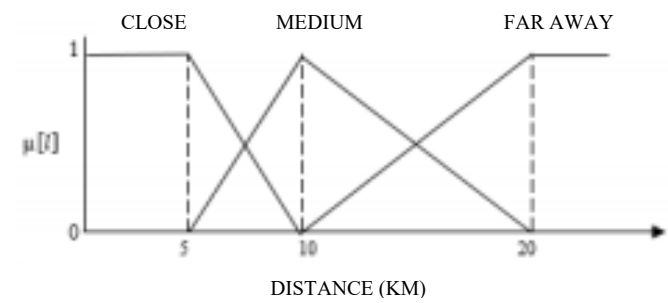

Fig.5. Graphs of Distance Location Membership Functions

After knowing the results of distance membership functions that have different values, namely Near, Medium, and Far, the results obtained in the following table are tourism data based on the distance of the location and the degree of membership in each set.

\section{Implementation}

\subsection{Display of Tourist Lists}

Figure 6 is a view of the list page for each tour, this page contains tourism data that will be entered, edited, added or deleted. This menu can be updated by the Administrator. 


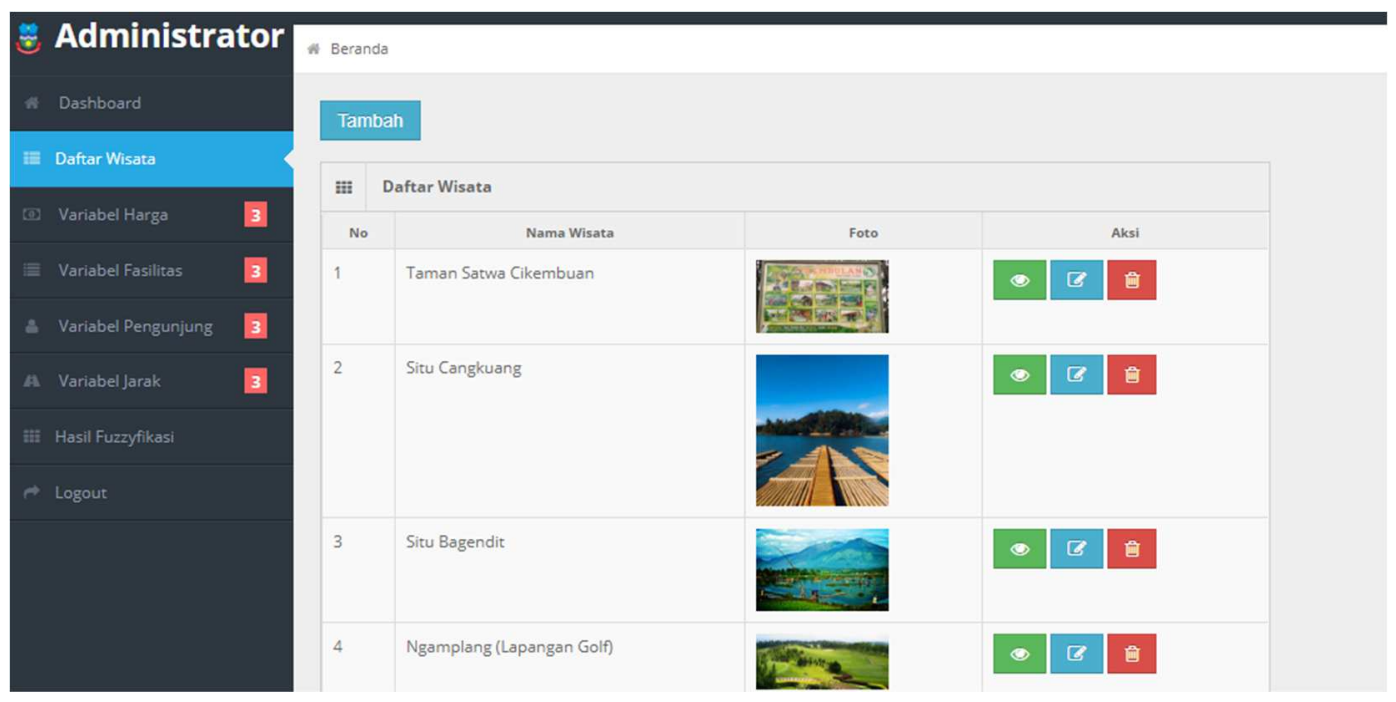

Fig 6. Implementation of the Tourist List Page

\subsection{Implementation of Price Variable Views}

Fig. 7 below is a display of the Price Variable page, in which there are 3 parts namely price list, price criteria set, and price membership degree.

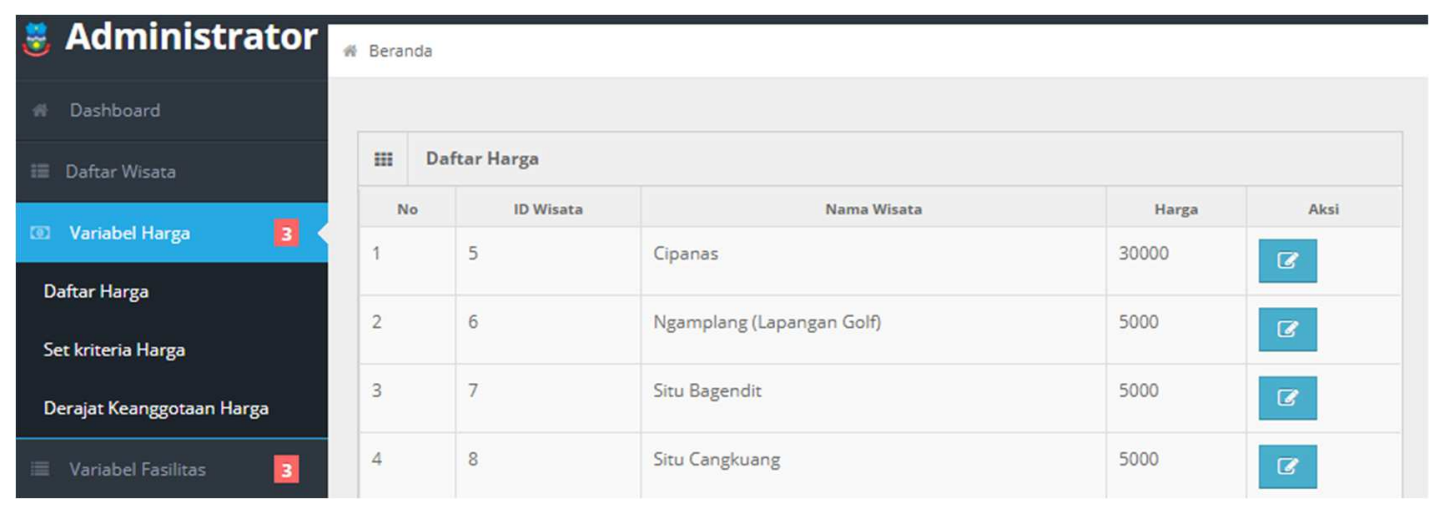

Fig 7. Display of Price List 


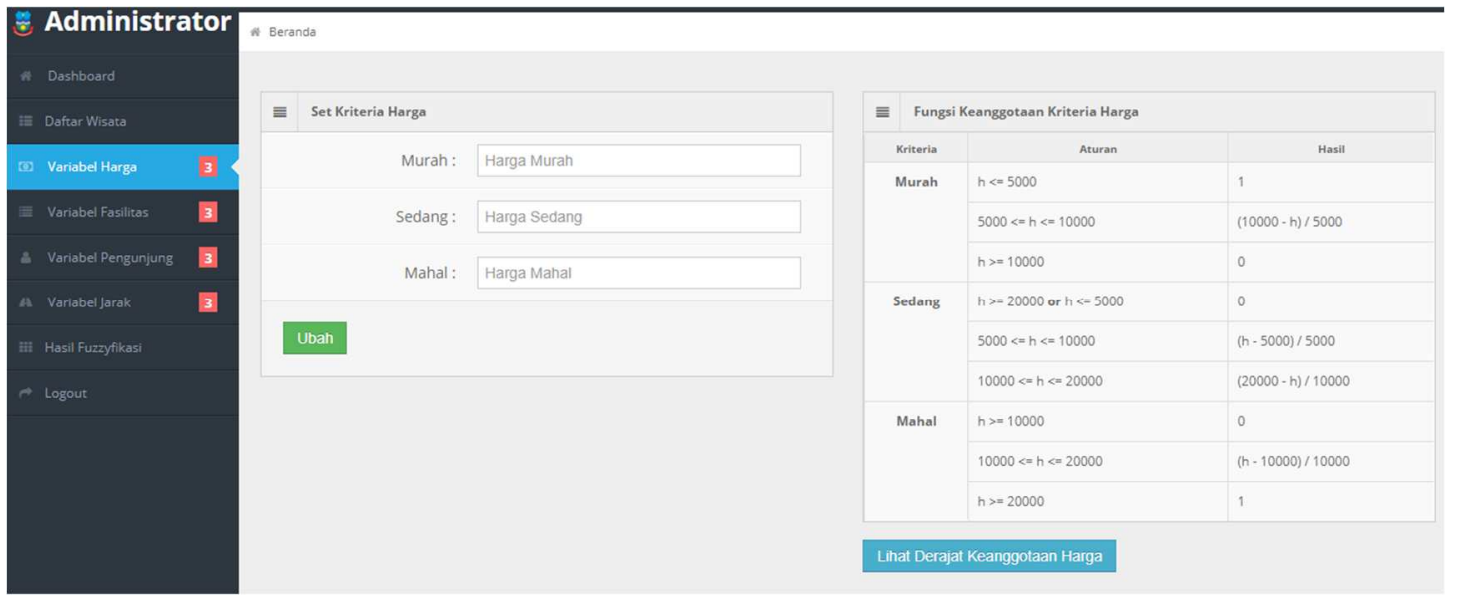

Fig 8. Display of Price Criteria Set
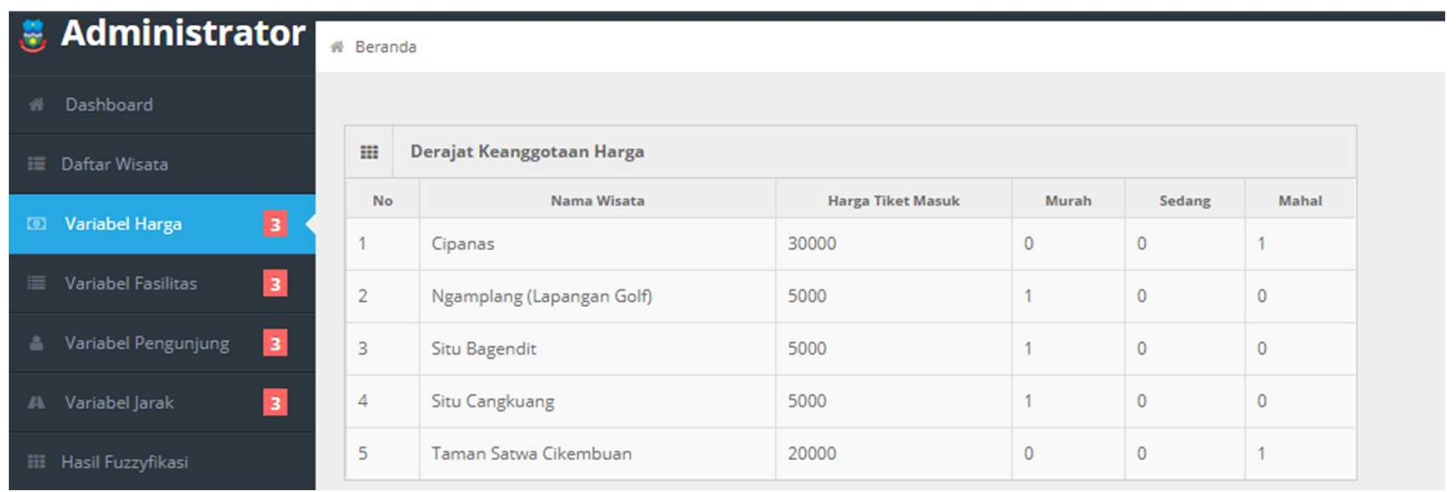

Fig 9. Implementation of Price Membership Degree

\subsection{Implementation of Display Fuzzyfication Results}

Figure 10 below this is the display of the admin page, where this page shows the results of loyal calculations entered by the admin. 


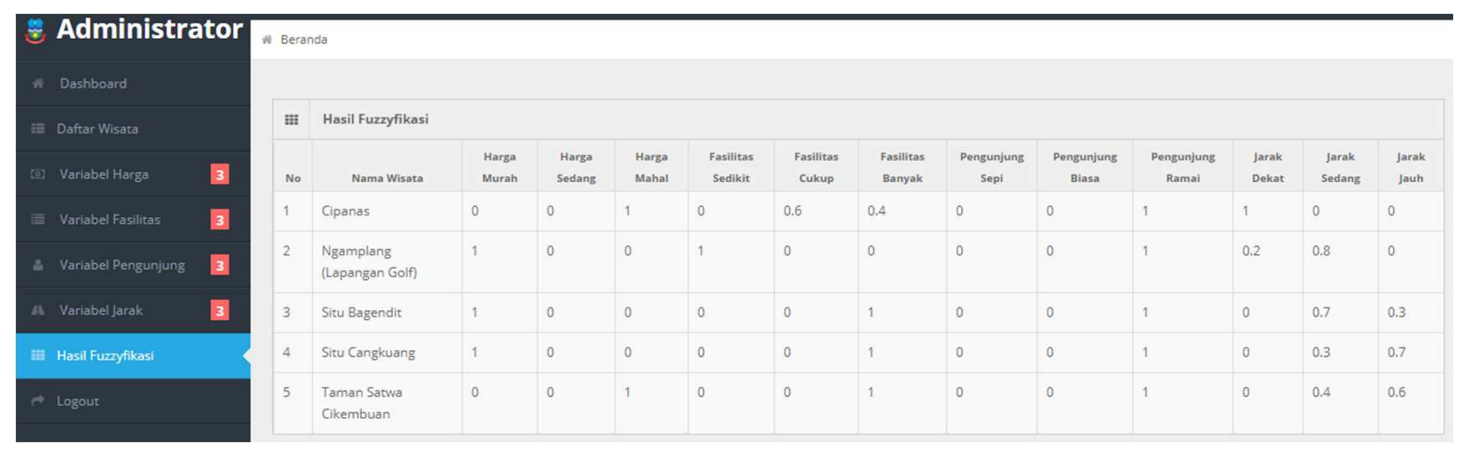

Fig 10. Implementation of Display Fuzzyfication Results

\subsection{User Interface Implementation}

Figure 11 below is a display of the main page or homepage, this page is the main page that provides a menu for selecting the tourism criteria needed and information on tourist attractions.

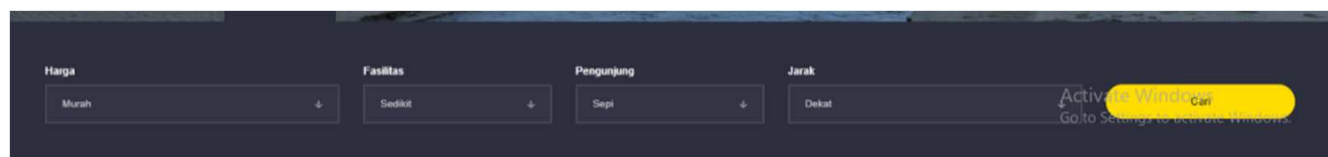

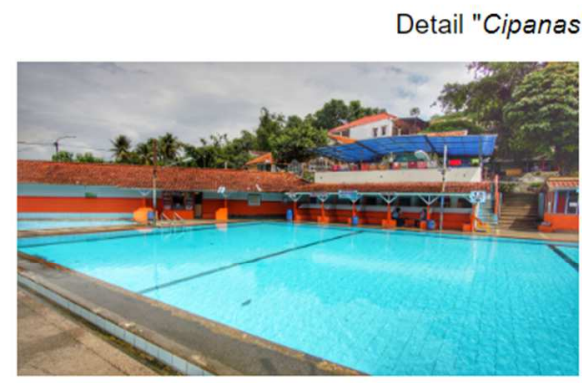

Tiket Masuk Rp 30000

Cipanas

303831 Total Penguniung

Terdapat 12 Fasitas

Lokasi: Kmp. Cipanas Desa : Rancabango/Cimanganten/Pananjung Kecamatan : Tarogong Kaler Kabupaten : Garut

Cari Lagi Wisata

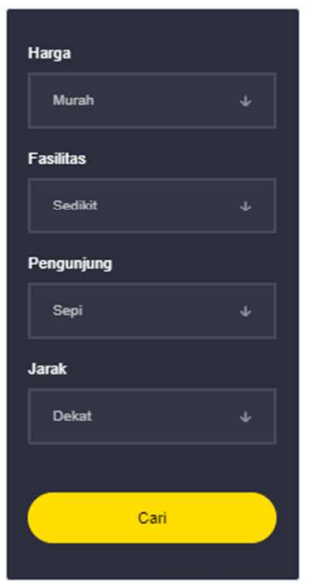

Daya Tarik : Wisata Alam Gunung Guntur Wisata alam Air Panas Kolam Renang Taman Air Panas Wisata Buatan Paraglading Gunung Guntur Pelaku Usaha Parawisata Wisata Belanja Cinderamata Kuliner Sentra Oleh oleh di Sepanjang Jalan Otist Adventur Sepeda Gunung Desa Wisata Luas Lokasi yang sudah digunakan : $30 \mathrm{Ha}$ Luas Lokasi pengembangan : $270 \mathrm{Ha}$

Fig 11. Home Screen Display 


\section{Testing}

Testing is a checking process to find errors or shortcomings that might occur in the software. Testing on the tourist recommendation system is done by testing the functionality commonly called black-box testing. The following are the results of testing the product sales forecasting system using the black-box testing method.

Table 3. Black Box Testing Result

\begin{tabular}{|c|c|c|c|c|}
\hline No & Class Test & \multicolumn{2}{|r|}{ Test Item } & Result \\
\hline \multirow[t]{2}{*}{1} & \multirow[t]{2}{*}{ Admin Login } & \multirow{2}{*}{\multicolumn{2}{|c|}{$\begin{array}{l}\text { Displays a warning when logging in by clearing the username and pass. } \\
\text { Enter the admin page when filling in the correct username and correct } \\
\text { password. }\end{array}$}} & $\sqrt{ }$ \\
\hline & & & & $\sqrt{ }$ \\
\hline \multirow[t]{5}{*}{2} & \multirow{5}{*}{$\begin{array}{l}\text { Tourist List } \\
\text { Menu }\end{array}$} & a) & Add tourist data and the system will save it. & $\sqrt{ }$ \\
\hline & & & Showing a warning when adding tourist data is missing. & $\sqrt{ }$ \\
\hline & & & Edit tourist data and the system can save the edited data. & $\sqrt{ }$ \\
\hline & & d) & Clear tourist data and the system deletes selected tourism data. & $\sqrt{ }$ \\
\hline & & & See details of edits and can display them. & $\sqrt{ }$ \\
\hline \multirow[t]{16}{*}{3} & \multirow{16}{*}{$\begin{array}{l}\text { Various } \\
\text { Variable } \\
\text { Criteria }\end{array}$} & a) & Make additional prices for tourist attractions and store them. & $\sqrt{ }$ \\
\hline & & b) & Edit price data and save it. & $\sqrt{ }$ \\
\hline & & c) & Set price criteria and enter the price membership level. & $\sqrt{ }$ \\
\hline & & d) & Add facility data and save it. & $\sqrt{ }$ \\
\hline & & e) & Edit facility data and save it. & $\sqrt{ }$ \\
\hline & & f) & $\begin{array}{l}\text { Set the criteria for facilities and enter the degree of membership of } \\
\text { the facility. }\end{array}$ & $\sqrt{ }$ \\
\hline & & g) & Add visitor data and save it. & $\sqrt{ }$ \\
\hline & & h) & Edit visitor data and save it. & $\sqrt{ }$ \\
\hline & & i) & Set visitor criteria and enter the visitor membership level. & $\sqrt{ }$ \\
\hline & & j) & Perform additional distance data and save it. & $\sqrt{ }$ \\
\hline & & k) & Edit distance data and save it. & $\sqrt{ }$ \\
\hline & & & Set distance criteria and enter in distance membership degrees. & $\sqrt{ }$ \\
\hline & & $\mathrm{m})$ & $\begin{array}{l}\text { Displays fuzzification from the calculation results from the set of } \\
\text { each variable data. }\end{array}$ & $\sqrt{ }$ \\
\hline & & n) & Logout. & $\sqrt{ }$ \\
\hline & & o) & Exit when logging out & $\sqrt{ }$ \\
\hline & & p) & Return to the login page when successfully logging out. & $\sqrt{ }$ \\
\hline \multirow[t]{2}{*}{4} & $\begin{array}{l}\text { Selection of } \\
\text { Criteria by }\end{array}$ & a) & $\begin{array}{l}\text { The User Selects Existing Criteria and the system provides } \\
\text { recommendations according to the criteria selected. }\end{array}$ & $\sqrt{ }$ \\
\hline & Users & b) & Showing recommendations on tourist attractions. & $\sqrt{ }$ \\
\hline \multirow[t]{2}{*}{5} & $\begin{array}{l}\text { Calculation } \\
\text { with } \\
\text { Algorithm }\end{array}$ & a) & $\begin{array}{l}\text { Addition of tourist data in the form of prices, visitors, distance, and } \\
\text { facility algorithms classify each tourist data according to the } \\
\text { weighting criteria. }\end{array}$ & $\sqrt{ }$ \\
\hline & & b) & $\begin{array}{l}\text { Generate recommendations on tourist attractions from the results } \\
\text { of calculations. }\end{array}$ & $\sqrt{ }$ \\
\hline
\end{tabular}




\section{Conclusion}

Fuzzy Tahani algorithm can be implemented to provide recommendations for tourist attractions in Garut Regency. This information system can provide recommendations based on prices, the number of visitors, facilities available at tourist attractions, and distance from tourist sites. Based on Black box testing, the system can pass the test stage and provide satisfactory results. This means that the information system that provides recommendations for tourism places with Fuzzy Tahani is going well.

\section{Future Works}

The ideas or suggestions that can be used as material for improvement, development or improvement of this implementation in the future include: (1) making favorite features on tourist info, where users can save favorite tourist attractions that they want to see again, (2) adding directions directions to recommended attractions, and (3) adding recommendations on lodging, dining, and hospitals.

\section{References}

[1] Irwan Syambudi, "BPS: Indonesia Dikunjungi 15,81 Juta Turis Sepanjang 2018 - Tirto.ID." [Online]. Available: https://tirto.id/bps-indonesia-dikunjungi-1581-juta-turis-sepanjang-2018-dfGP. [Accessed: 19-Jul-2019].

[2] Silvita Agmasari, "Tak Capai Target, Jumlah Wisman ke Indonesia Tahun 2018 Sebanyak 15,81 Juta." [Online]. Available: https://travel.kompas.com/read/2019/02/01/180500527/tak-capai-targetjumlah-wisman-ke-indonesia-tahun-2018-sebanyak-15-81-juta. [Accessed: 19-Jul-2019].

[3] Syike Febrina Laucereno, “14,4 Juta Turis Asing Masuk RI, Paling Banyak dari Malaysia.”[Online]. Available: https://finance.detik.com/berita-ekonomi-bisnis/d-4367885/144-juta-turis-asing-masuk-ripaling-banyak-dari-malaysia. [Accessed: 19-Jul-2019].

[4] Yulistyne Kasumaningrum, "Kunjungan Wisatawan Mancanegara ke Jabar Meningkat 16,4\% Pikiran Rakyat." [Online]. Available: https://www.pikiran-rakyat.com/ekonomi/2019/04/23/kunjunganwisatawan-mancanegara-ke-jabar-meningkat-164. [Accessed: 19-Jul-2019].

[5] Bill Clinten, "10 Kota Tujuan Wisata Terpopuler di Indonesia Menurut Google." [Online]. Available: https://tekno.kompas.com/read/2018/10/09/17320017/10-kota-tujuan-wisata-terpopuler-diindonesia-menurut-google. [Accessed: 19-Jul-2019].

[6] Jayadi Supriadin, "10 Potensi Wisata Garut yang Akan Dikebut - Regional Liputan6.com.” [Online]. Available: https://www.liputan6.com/regional/read/3876071/10-potensi-wisata-garut-yang-akan-dikebut. [Accessed: 19-Jul-2019].

[7] E. H. Hidayat, "Implementasi Fuzzy Model Tahani Untuk Perancangan Sistem Pendukung Keputusan Penerimaan Taruna Baru,” J. Sist. Inf. Bisnis, vol. 5, no. 1, pp. 63-71, 2015.

[8] H. Kusumadewi,Sri. Purnomo, "Logika fuzzy tahani sistem penunjang keputusan penentuan lulusan terbaik," J. Inform., vol. 3, no. III, pp. 31-40, 2016.

[9] "PENERAPAN FUZZY DATABASE MODEL TAHANI DALAM SISTEM PENDUKUNG KEPUTUSAN PEMILIHAN MOBIL SEWA (Studi Kasus: Penyewaan Mobil di Daerah Istimewa Yogyakarta)."

[10] G. Taufiq, "Logika Fuzzy Tahani Untuk Pendukung Keputusan Perekrutan Karyawan Tetap,” Pros. Semin. Nas. Apl. Sains Teknol., no. November, pp. 99-106, 2014.

[11] A. Sanjaya and R. Ningsih, "SISTEM PENDUKUNG KEPUTUSAN PENENTUAN CALON PENERIMA BEASISWA MENGGUNAKAN METODE FUZZY DATABASE MODEL TAHANI," Simetris J. Tek. Mesin, Elektro dan Ilmu Komput., vol. 7, no. 2, p. 449, Nov. 2016. 
[12] S. Widodo and V. G. Utomo, "Rancang Bangun Aplikasi Travel Recommender Berbasis Wap Menggunakan Metode Fuzzy Model Tahani,” J. Teknol. Inf. dan Komun. STMIK ProVisi Semarang, vol. 5, no. 1, pp. 25-34, 2014.

[13] S. Kusumadewi, "teknik-dan-aplikasi-AI," 2003.

[14] A. Lia and Z. B. Fananie, "Model Fuzzy Tahani Untuk Pemodelan Sistem Pendukung Keputusan (SPK)," no. May, 2016. 